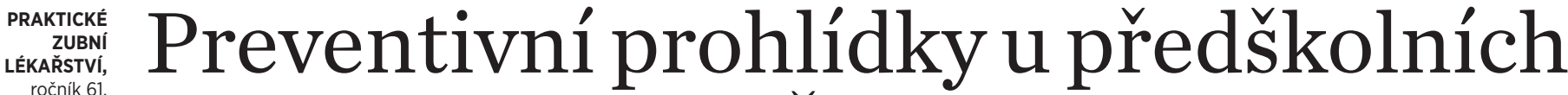 a školních dětí v ČR v letech 2001-2010 a jejich trendy
}

(Originální práce - statistická studie)

\section{Dental Check-Ups in Czech Preschool and School Children in 2001-2010 and their Trends}

(Original Article - Statistic Study)

\section{Broukal Z, Lenčová E., Lišková K.}

Ústav klinické a experimentální stomatologie 1. LF UK a VFN, Praha

\section{SOUHRN}

Cílem studie bylo zjistit objem preventivních stomatologických prohlídek u dětí ve věku 0-14 let v roce 2010 a stanovit jejich trend z dat poslední dekády počínaje rokem 2001.

Materiál a metody: Z datových souborů o poskytnuté stomatologické péči pojištěncům VZP byly extrahovány tyto údaje: kód oblasti VZP, datum provedeného výkonu, číslo pojištěnce a kódy provedených výkonů (prohlídky, výplně a extrakce). Z dat byly kalkulovány tyto ukazatele: procento dětí prohlédnutých stomatologem alespoň jedenkrát v roce, z nich procento dětí prohlédnutých dvakrát za rok, procento dětí, které v daném roce neabsolvovaly stomatologickou prohlídku, procento dětí, u kterých bylo současně s prohlídkou provedeno konzervační ošetření (výplně), a procento dětí, u kterých bylo současně s prohlídkou provedeno chirurgické ošetření (extrakce). Data byla zpracována pro věkové skupiny 2-3, 3-6, 6-10 a 10-14 let za léta 2001-2010. Statistické metody - porovnání četností prohlídek - Snedecorův $\chi 2$ test s Yatesovou korekcí, trendy změn četností jednotlivých ukazatelů lineární regrese na 95\% hladině významnosti $(p=0,05)$.

Výsledky: $\vee$ roce 2010 absolvovalo stomatologickou prohlídku alespoň jedenkrát v roce ve věku 2-3 let $66,7 \%$ dětí, z nich bylo 28,6 \% prohlédnuto dvakrát. Ve věku 3-6 let tyto údaje činily 66,4 \%/31,8 \%, u 6-10letých 84,2 \%/58,8 \% a u 10-14letých 71,1 \%/55,8 \%. V průběhu let 2001-2010 se u 2-3letých dětí signifikantně zvýšil podíl dětí prohlédnutých alespoň jedenkrát a mezi prohlédnutými se signifikantně zvýšil podíl dětí prohlédnutých dvakrát v roce. U starších předškolních dětí se v prủběhu minulé dekády ukazatele preventivních prohlídek signifikantně neměnily. Četnosti dětí ve školním věku, prohlédnutých alespoň jedenkrát v roce, se významně neměnily, zhruba $85 \%$ dětí absolvovalo preventivní prohlídku alespoň jedenkrát v roce. Ve věkových skupinách 6-10letých a 10-14letých však signifikantně vzrostl podíl dětí vyšetřených dvakrát ročně.

Závěr: Přestože se stav chrupu a potřeba ošetření ve sledovaných ukazatelích v naší dětské populaci zlepšuje, ukazatele preventivních prohlídek a trend jejich vývoje v posledních letech ukazuje slabiny současného systému dětské stomatologické péče, který nemá účinné nástroje na zvýšení dostupnosti preventivních prohlídek u předškolních a školních dětí.

Klíčová slova: preventivní stomatologické prohlídky - předškolní a školní děti - VZP 


\section{SUMMARY}

The aim of the study was to determine frequency and structure of preventive dental check-ups in children aged 0-14 years in 2010 and to assess their trend in the last decade (2001-2010).

Material and methods: The following data were extracted from datasets on dental care provided to children covered by the General Health Insurance Fund of the Czech Republic: geographical area code, date of the check-up, child's ID and codes of procedures provided during the check-up (check-up, filling, extraction). Calculated parameters for the age-groups of 2-3, 3-6, 6-10 and 10-14 years: per cent seen by a dentist at least once a year, per cent seen twice a year, per cent of check-ups, which included restorative treatment (fillings) or tooth extractions.

Statistical methods: Comparison of check-up frequencies - Snedecor's $\chi^{2}$ test with Yates correction, trends in check-up frequencies - linear regression, both at the significance of $95 \%(p=0.05)$.

Results: 2010: at the age of $2-3$ years $66.7 \%$ of children visited dentist at least once a year, $28.6 \%$ of them visited dentist twice. At the age of 3-6 years the proportions were $66.4 \% / 31.8 \%$, respectively, at $6-10 \mathrm{yrs}$ $84.2 \% / 58.8 \%$, respectively, and at $10-14$ yrs $71.1 \%$ / 55.8\%, respectively. Over the period 2001-2010, the percentage of 2-3 yr-olds seen at least once a year or twice a year increased significantly $(p=0.001)$. The frequency of check-ups in older preschool children did not change. About $85 \%$ of school children were seen at least once a year and the proportions of 6-10 and 10-14 yr-olds seen twice a year increased significantly $\left(p_{6-10}=0.001, p_{10-14}=0.012\right.$, resp. $)$.

Conclusion: Despite the fact that caries experience and treatment needs in Czech paediatric population declined over the investigated period, the trend in indicators of preventive dental care improved only partially, reflecting weaknesses of a current preventive health care system that lacks effective tools and incentives to enhance accessibility of preventive dental check-ups to preschool and school children.

\section{Key words: dental attendance - dental check-ups - preschool and school children - General Health Insurance Fund}

Prakt. zub. Lék., roč. 61, 2013, č.2, s. 20-28

\section{ÚVOD}

Pravidelné preventivní prohlídky jsou důležitou součástí primární stomatologické péče a u pojištěnců je jejich úhrada ze zdravotního pojištění a jejich frekvence zakotvena v zákoně č. $48 / 1997 \mathrm{Sb}$. o veřejném zdravotním pojištění [19] a ve vyhlášce $M Z$ ČR Č. 3/2010 o stanovení obsahu a časového rozmezí preventivních prohlídek [16] ve znění pozdějších předpisů. Podle citované vyhlášky se preventivní prohlídky v oboru stomatologie provádějí jedenkrát ročně $u$ dětí $v$ prvním roce života a dvakrát ročně u dětí a dorostu od jednoho roku do 18 let věku.

Smyslem prohlídek je včasné zavzetí dětí do pravidelné stomatologické péče a včasné zjištování chorobných změn v dutině ústní, které vyžadují odpovídající ošetření nebo léčbu. Legislativní podklad prohlídek má za cíl zajistit jejich plošnost a dostupnost pro celou dětskou populaci.

Povinností rodičư resp. zákonných zástupcư dětí je zajistit pro dítě stomatologickou péči a pravidelně je objednávat a doprovázet k preventivním prohlídkám, popřípadě k následnému ošetření.

V současném výkaznictví v rámci Národního zdravotního informačního systému se však preventivní stomatologické prohlídky nesledují.

Daty o provedených preventivních prohlídkách disponují pouze zdravotní pojištovny, do kterých přicházejí ze stomatologických zařízení dávkové soubory o výkonech v poskytované péči, a pojištovny jsou tak jediným zdrojem dat o provedených stomatologických prohlídkách.

Ve snaze získat údaje o provedených preventivních prohlídkách jsme již dříve požádali jednotlivé zdravotní pojištovny o poskytnutí příslušných datových souborů $\mathrm{k}$ analýze. Požadavku vyhověla Všeobecná zdravotní pojištovna, která pro účely analýz objemu preventivních stomatologických prohlídek u dětí poskytuje každoročně data, počínaje rokem 2001.

Cílem studie bylo zjistit objem preventivních stomatologických prohlídek u dětí ve věku 0-14 let 
$\mathrm{v}$ roce 2010 a stanovit jejich trend $\mathrm{z}$ dat poslední dekády počínaje rokem 2001.

\section{MATERIAL A METODY}

\section{Demografická data dětí - pojištěnců VZP}

Podle údajů Českého statistického úřadu bylo v roce 2010 v České republice 1542934 dětí ve věku do 15 let [4], z nichž 797082 bylo pojištěno ve Všeobecné zdravotní pojištovně [17], tedy zhruba 52 procent ze všech dětí (tab. 1). Ve sledovaném období 2001-2010 podíl dětí 0-15 let, pojištěných ve VZP z celkového počtu dětí v populaci, mírně klesal z 65 procent $\mathrm{v}$ roce 2001 k 52 procentům v roce 2010.

\section{Datové soubory}

Datové soubory o poskytnuté stomatologické péči, připravené Oddělením analýz VZP pro účely této

\begin{tabular}{|c|c|c|c|c|c|c|c|c|c|c|c|c|}
\hline \multirow{3}{*}{ Věk } & \multirow{3}{*}{$\mathrm{C}^{*}$} & \multicolumn{2}{|l|}{2010} & 2009 & 2008 & 2007 & 2006 & 2005 & 2004 & 2003 & 2002 & 2001 \\
\hline & & \multicolumn{11}{|l|}{ VZP** } \\
\hline & & $n$ & \multicolumn{10}{|l|}{$\%$} \\
\hline $0-5$ & 586632 & 306067 & 51,8 & 50,7 & 53,3 & 54,8 & 55,3 & 55,9 & 56,1 & 57,7 & 60,1 & 63,6 \\
\hline $5-10$ & 499265 & 251953 & 50,6 & 49,8 & 52,8 & 53,6 & 56 & 57,4 & 58,9 & 60,8 & 63,5 & 66,3 \\
\hline $10-15$ & 457037 & 239062 & 53,2 & 53,5 & 56,2 & 58,2 & 59,2 & 60,2 & 60,9 & 62,4 & 64,1 & 66,3 \\
\hline $0-15$ & 1542934 & 797082 & & & & & & & & & & \\
\hline \multicolumn{3}{|c|}{ průměr } & 51,9 & 51,3 & 54,1 & 55,5 & 56,8 & 57,8 & 58,6 & 60,3 & 62,6 & 65,4 \\
\hline
\end{tabular}

Tab. 2 Kódy výkonů stomatologické péče [6]

\begin{tabular}{|l|l|}
\hline Kód & Výkon \\
\hline $00900(901)$ & Komplexní vyšetřeni stomatologem při registraci pojištěnce \\
\hline $00901(902)$ & Opakované komplexní vyšetření a ošetření registrovaného pojištěnce - preventivní prohlídka \\
\hline 00920 & Ošetření zubního kazu - stálý zub - fotokompozitní výplň \\
\hline 00921 & Ošetření zubního kazu - stálý zub \\
\hline 00922 & Ošetření zubního kazu - dočasný zub \\
\hline 00949 & Extrakce dočasného zubu \\
\hline 00950 & Extrakce stálého zubu \\
\hline
\end{tabular}

Tab. 3 Kalkulované ukazatele prohlídek a akutního ošetření

\begin{tabular}{|l|l|l|}
\hline \multicolumn{2}{|l|}{ Procento dětí prohlédnutých stomatologem alespoň jedenkrát v roce } & Kód \\
\hline \multirow{2}{*}{ z toho } & procent dětí prohlédnutých 2x za rok & 00900 nebo 00901 \\
\cline { 2 - 3 } & procent dětí prohlédnutých 1x za rok & $00900+00901$ \\
\cline { 2 - 3 } & procent dětí, které v daném roce neabsolvovaly stomatologickou prohlídku & - \\
\hline $\begin{array}{l}\text { Procento dětí, u kterých bylo současně s prohlídkou provedeno konzervační ošetření } \\
\text { (výplně) }\end{array}$ & $\begin{array}{l}00900 \\
\text { nebo } 00922\end{array}$ \\
\hline $\begin{array}{l}\text { Procento dětí, u kterých bylo současně s prohlídkou provedeno chirurgické ošetření } \\
\text { (extrakce) }\end{array}$ & 00900 nebo $00901+00949$ nebo 00950 \\
\hline
\end{tabular}




\begin{tabular}{|c|c|c|c|c|c|c|c|c|c|c|}
\hline Věk & \multicolumn{5}{|c|}{ 2-3 roky } & \multicolumn{5}{|c|}{ 3-6 let } \\
\hline \multirow{3}{*}{2010} & \multirow{3}{*}{$\mathrm{n}$} & \multirow{3}{*}{$\begin{array}{c}\begin{array}{c}\text { prohléd- } \\
\text { nuty } \\
\text { alespoň } 1 x\end{array} \\
\%\end{array}$} & \multicolumn{2}{|c|}{ z toho prohlédnuty } & \multirow{2}{*}{$\begin{array}{l}\text { nepro- } \\
\text { hlédnuty } \\
\text { v daném } \\
\text { roce }\end{array}$} & \multirow{3}{*}{$\mathrm{n}$} & \multirow{2}{*}{$\begin{array}{l}\text { prohléd- } \\
\text { nuty } \\
\text { alespoň 1x }\end{array}$} & \multicolumn{2}{|c|}{$\mathrm{z}$ toho prohlédnuty } & \multirow{2}{*}{$\begin{array}{c}\text { nepro- } \\
\text { hlédnuty } \\
\text { v daném } \\
\text { roce } \\
\end{array}$} \\
\hline & & & $2 x$ & $1 x$ & & & & $2 x$ & $1 x$ & \\
\hline & & & $\%$ & $\%$ & $\%$ & & $\%$ & $\%$ & $\%$ & $\%$ \\
\hline Praha & 12011 & $\uparrow 72,3$ & $\uparrow 38,6$ & 61,4 & 27,7 & 17888 & $\uparrow 78,7$ & $\uparrow 41,2$ & 58,8 & 21,3 \\
\hline SČ & 20295 & 68,5 & 26,8 & 73,2 & 31,5 & 28348 & 69,4 & $\uparrow 36,0$ & 64,0 & 30,6 \\
\hline JČ & 9457 & $\uparrow 71,2$ & $\uparrow 33,7$ & 66,3 & 28,8 & 14546 & 64,8 & 31,0 & 69,0 & 35,2 \\
\hline$P L$ & 8517 & $\uparrow 70,6$ & 23,8 & 76,2 & 29,4 & 13100 & $\uparrow 70,5$ & $\uparrow 36,4$ & 63,6 & 29,5 \\
\hline KV & 4608 & 68,5 & 24,8 & 75,2 & 31,5 & 7088 & $\uparrow 71,5$ & 35,8 & 64,2 & 28,5 \\
\hline UL & 13009 & $\downarrow 60,9$ & $\downarrow 19,6$ & 80,4 & $\uparrow 39,1$ & 20008 & 66,2 & $\downarrow 28,8$ & 71,2 & 33,8 \\
\hline LI & 6855 & 63,8 & $\uparrow 36,8$ & 63,2 & $\uparrow 36,2$ & 10543 & 63,4 & 29,4 & 70,6 & $\uparrow 36,6$ \\
\hline $\mathrm{HK}$ & 8258 & $\downarrow 60,7$ & 37,1 & 62,9 & $\uparrow 39,3$ & 12701 & $\downarrow 62,4$ & 30,2 & 69,8 & $\uparrow 37,6$ \\
\hline PU & 7678 & $\downarrow 62,3$ & $\uparrow 37,1$ & 62,9 & $\uparrow 37,7$ & 11810 & 66,9 & 29,5 & 70,5 & 33,1 \\
\hline VY & 7360 & $\downarrow 61,8$ & $\downarrow 15,3$ & 84,7 & $\uparrow 38,2$ & 11321 & $\downarrow 59,1$ & $\downarrow 26,5$ & 73,5 & $\uparrow 40,9$ \\
\hline$J M$ & 17050 & 69,8 & 28,7 & 71,3 & 30,2 & 26048 & 63.0 & $\downarrow 28,6$ & 71,4 & $\uparrow 37,0$ \\
\hline $\mathrm{OL}$ & 9393 & 69,5 & $\uparrow 37,9$ & 62,1 & 30,5 & 14436 & 65,9 & 31,2 & 68,8 & 34,1 \\
\hline ZL & 7303 & $\downarrow 62,3$ & $\downarrow 16,8$ & 83,2 & $\uparrow 37,7$ & 11247 & $\downarrow 56,5$ & $\downarrow 25,8$ & 74,2 & $\uparrow 43,5$ \\
\hline MS & 14552 & $\uparrow 71,4$ & 23,1 & 76,9 & 28,6 & 21233 & 69,3 & 34,2 & 65,8 & 30,7 \\
\hline celkem & 146353 & & & & & 220321 & & & & \\
\hline průměry & & 66,7 & 28,6 & 71,4 & 33,3 & & 66,4 & 31,8 & 68,2 & 33,7 \\
\hline
\end{tabular}

RAKTICKE

ZUBNI

LÉKAŘSTVÍ,

ročník 61

2013, 2

s. $20-28$

\begin{tabular}{|c|c|c|c|c|c|c|c|c|c|c|}
\hline \multirow{4}{*}{$\begin{array}{l}\text { Věk } \\
2010\end{array}$} & \multicolumn{5}{|c|}{ 6-10 let } & \multicolumn{5}{|c|}{ 10-14 let } \\
\hline & \multirow{3}{*}{$\mathrm{n}$} & \multirow{3}{*}{$\begin{array}{c}\text { prohlédnuty } \\
\text { alespoň } 1 \mathrm{x} \\
\% \\
\end{array}$} & \multicolumn{2}{|c|}{$\mathrm{z}$ toho prohlédnuty } & \multirow{3}{*}{$\begin{array}{c}\text { neprohléd- } \\
\text { nuty } \\
\text { v daném } \\
\text { roce }\end{array}$} & \multirow{3}{*}{$\mathrm{n}$} & \multirow{3}{*}{$\begin{array}{c}\begin{array}{c}\text { prohléd- } \\
\text { nuty } \\
\text { alespoň 1x }\end{array} \\
\%\end{array}$} & \multicolumn{2}{|c|}{ z toho prohlédnuty } & \multirow{2}{*}{$\begin{array}{l}\text { neprohléd- } \\
\text { nuty } \\
\text { v daném } \\
\text { roce }\end{array}$} \\
\hline & & & $2 x$ & $1 x$ & & & & $2 x$ & $1 x$ & \\
\hline & & & $\%$ & $\%$ & & & & $\%$ & $\%$ & $\%$ \\
\hline Praha & 27481 & $\uparrow 90,3$ & $\uparrow 82,6$ & 17,4 & 9,7 & 31601 & $\uparrow 82,4$ & $\uparrow 79,6$ & 20,4 & 17,6 \\
\hline SČ & 23332 & 84,4 & $\uparrow 74,0$ & 26.0 & 15,6 & 26911 & 74,4 & $\uparrow 71,3$ & 29.0 & 25,6 \\
\hline JČ & 11252 & 83,6 & $\uparrow 75,0$ & 25.0 & 16,4 & 14915 & 72,4 & $\uparrow 72,0$ & 28.0 & 27,6 \\
\hline $\mathrm{PL}$ & 9754 & 85,2 & 56,2 & 43,8 & 14,8 & 12555 & 62,3 & 53,2 & 46,8 & $\uparrow 37,7$ \\
\hline $\mathrm{KV}$ & 5512 & $\downarrow 75,4$ & $\downarrow 46,8$ & 53,2 & $\uparrow 24,6$ & 7236 & 65,5 & $\downarrow 43,8$ & 56,2 & $\uparrow 34,5$ \\
\hline UL & 15953 & 83,3 & 52,1 & 47,9 & 16,7 & 20367 & 62,1 & $\downarrow 49,1$ & 50,9 & $\uparrow 37,9$ \\
\hline $\mathrm{LI}$ & 7955 & $\downarrow 78,4$ & $\downarrow 46,9$ & 53,1 & $\uparrow 21,6$ & 10586 & $\uparrow 76,8$ & $\downarrow 43,9$ & 56,1 & 23,2 \\
\hline HK & 9699 & $\uparrow 90,4$ & 56,2 & 43,8 & 9,6 & 13048 & 74,8 & 53,2 & 46,8 & 25,2 \\
\hline PU & 9060 & 85,3 & 52,8 & 47,2 & 14,7 & 12543 & 75,1 & $\downarrow 49,8$ & 50,2 & 24,9 \\
\hline VY & 9063 & 85,1 & 56,3 & 43,7 & 14,9 & 12534 & $\uparrow 76,8$ & 53,3 & 46,7 & 24.0 \\
\hline$J M$ & 18983 & $\downarrow 78,8$ & $\downarrow 45,2$ & 54,8 & $\uparrow 21,2$ & 24253 & 72,2 & $\downarrow 42,2$ & 57,8 & 27,8 \\
\hline $\mathrm{OL}$ & 11118 & 88,0 & $\uparrow 68,7$ & 31,3 & 12.0 & 14744 & 71,2 & $\uparrow 65,7$ & 34,3 & 28,8 \\
\hline ZL & 9129 & $\uparrow 90,6$ & 61,5 & 38,5 & 9,4 & 12316 & 62,1 & 58,5 & 41,5 & $\uparrow 37,9$ \\
\hline MS & 19362 & 80,1 & $\downarrow 48,6$ & 51,4 & 19,9 & 22061 & 68,5 & $\downarrow 45,6$ & 54,4 & $\uparrow 31,5$ \\
\hline celkem & 187658 & & & & & 235675 & & & & \\
\hline průměry & & 84,2 & 58,8 & 42,2 & 15,8 & & 71,1 & 55,8 & 44,2 & 28,9 \\
\hline
\end{tabular}

$\downarrow \uparrow$ signifikantní rozdíl proti průměru $(p<0,05)$ 
studie, sestávaly z datových vět obsahujících tyto údaje: kód oblasti VZP, kód zdravotnického zařízení, datum, číslo pojištěnce a kódy provedených výkonů, případně jejich lokalizace. Pro ochranu dat byly kódy zdravotnických zařízení a čísla pojištěncư maskovány tak, aby nebylo možné zařízení a pojištěnce identifikovat, ale zároveň bylo možné zjistit, kolikrát byl v daném roce příslušný jedinec vyšetřen/ošetřen ve stejném nebo jiném stomatologickém zařízení.

Kódy oblasti VZP sloužily k filtraci datového souboru podle krajů a čísla pojištěnců byla použita ke stratifikaci souboru podle věku dětí. $Z$ vykázaných stomatologických výkonů byly zaznamenávány kódy uvedené v tabulce 2 .

\section{Sledované ukazatele prohlídek a akutního ošetření}

Ukazatele prohlídek (tab. 3) byly kalkulovány pro věkové skupiny 2-3letých, 3-6letých, 6-10letých a 10-14letých dětí.

\section{Statistické zpracování dat}

Kalkulované ukazatele prohlídek a akutního ošetření byly propočítány pro jednotlivé roky v období 2001-2010.

Pro porovnávání relativních četností (procenta) byl použit Snedecorův $\chi^{2}$ test s Yatesovou korekcí. Pouze tam, kde byly relativní četnosti příliš nízké, byl nahrazen Fisherovým exaktním testem čtyřpolní tabulky. Pro větší přesnost byly k výpočtu použity počty osob, nikoli vypočtená relativní čísla (procenta). Hladina významnosti byla zvolena jako $\mathrm{p}=0,05$. Trendy změn četností jednotlivých ukazatelů byly stanoveny výpočtem lineárních regresí příslušných dat ve sledovaném období na $95 \%$ hladině $(\mathrm{p}=0,05)$ s použitím SW Statistica 10.0 (StatSoft ČR, S.r.o.).

\section{VÝSLEDKY}

\section{Preventivní prohlídky u dětí v roce 2010 (tab. 4)}

Ve věku 2-3 let absolvovalo z pojištěnců VZP stomatologickou prohlídku alespoň jedenkrát v roce $66,7 \%$ dětí, z nich bylo $28,6 \%$ prohlédnuto dvakrát. Ve věku 3-6 let tyto údaje činily $66,4 \% / 31,8 \%$, u 6-10letých $84,2 \% / 58,8 \%$ a u 10-14letých 71,1\%/55,8\%.

V četnostech dětí podle jednotlivých ukazatelů preventivních prohlídek a podle věku byly zjištěny některé signifikantní rozdíly proti průměrným hodnotám z celého datového souboru, které jsou v tabulce označeny šipkami. Četnost dětí z Prahy byla ve všech věkových kategoriích signifikantně nad průměrem, jak pokud jde o děti prohlédnuté alespoň jedenkrát v roce, tak i pokud jde o podíl dětí, které absolvovaly dvě prohlídky v roce. V ostatních krajích se ukazatele preventivních prohlídek v jednotlivých věkových kategoriích signifikantně lišily od průměrů pro dané věkové kategorie, při pohledu na celé věkové pásmo od 2 do 14 let lze konstatovat, že ukazatele prohlídek se mezikrajově zásadně neliší.

\section{Trendy ukazatelů preventivních prohlídek v letech 2001-2010 (tab. 5)}

V průběhu let 2001-2010 se u 2-3letých dětí signifikantně zvýšil podíl dětí, prohlédnutých v jednotlivých letech alespoň jedenkrát a mezi prohlédnutými se signifikantně zvýšil podíl dětí prohlédnutých dvakrát v roce.

U starších předškolních dětí se v průběhu minulé dekády ukazatele preventivních prohlídek signifikantně neměnily, zhruba dvě třetiny dětí byly vyšetřeny alespoň jedenkrát $\mathrm{v}$ roce a $\mathrm{z}$ nich třetina byla vyšetřena dvakrát $v$ roce.

Četnosti dětí ve školním věku, prohlédnutých alespoň jedenkrát v roce, se významně neměnily, zhruba 85 \% dětí absolvovalo preventivní prohlídku alespoň jedenkrát $\mathrm{v}$ roce. Ve věkových skupinách 6-10letých a 10-14letých však signifikantně vzrostl podíl dětí vyšetřených dvakrát ročně.

\section{Výkony akutní péče v průběhu preventivních prohlídek v roce 2010 (tab. 6)}

U 48,9 \% 2-3letých dětí se preventivní prohlídky uskutečnily jako samostatný výkon, u 44,8 \% bylo současně vykázáno zhotovení výplní a u 6,3\% extrakce. U starších předškolních dětí byla prohlídka vykázána jako samostatný výkon u 46,8 \% prohlídek, ve 45,2\% případů byly zároveň vykázány výplně a v osmi procentech extrakce. U mladších školních dětí šlo v 48, 9 \% př́ipadů o samostatnou prohlídku, v 44,8\% byla zároveň zhotovena jedna nebo více výplní a ve 4,8 \% byl extrahován zub(y). Ve věku 10-14 let bylo 88,7\% preventivních prohlídek samostatných, v 7,6\% případů bylo zároveň provedeno konzervační ošetř̌ení a v 3,7 procentech extrakce.

\section{Trendy výkonů akutní péče v průběhu prohlídek v letech 2001-2010 (tab. 6)}

$\mathrm{V}$ průběhu sledovaného období se u obou věkových skupin předškolních dětí a u mladších školních dětí signifikantně zvýšil podíl dětí, u kterých se 
preventivní prohlídka uskutečnila jako samostatný výkon a signifikantně klesla četnost prohlídek u starších předškolních dětí, kdy se zároveň s prohlídkou provádělo konzervační ošetření. U 10-14letých se trend četností samostatných prohlídek nebo jejich kombinace s ošetřením výplněmi nebo extrakcemi signifikantně neměnil.

\section{DISKUSE}

Analýza četností preventivních stomatologických prohlídek u předškolních a školních dětí z datových souborů Všeobecné zdravotní pojištovny má některá omezení, která je při interpretaci dat pro celou naší dětskou populaci nutné brát v úvahu. V posledních

\begin{tabular}{|c|c|c|c|c|c|c|c|c|}
\hline \multirow[t]{3}{*}{ Věk } & \multicolumn{4}{|c|}{ 2-3 roky } & \multicolumn{4}{|c|}{ 3-6 let } \\
\hline & \multicolumn{3}{|c|}{ \% prohlédnutých } & \multirow{2}{*}{$\begin{array}{c}\% \\
\text { neprohléd- } \\
\text { nutých }\end{array}$} & \multicolumn{3}{|c|}{ \% prohlédnutých } & \multirow{2}{*}{$\begin{array}{c}\% \\
\text { neprohléd- } \\
\text { nutých }\end{array}$} \\
\hline & alespoň 1x & $z$ toho $2 x$ & $\mathrm{z}$ toho $1 \mathrm{x}$ & & alespoň $1 \mathrm{x}$ & $z$ toho $2 x$ & $\mathrm{z}$ toho $1 \mathrm{x}$ & \\
\hline 2001 & 49,1 & 18,6 & 81,4 & 50,9 & 67,4 & 35,4 & 64,6 & 32,6 \\
\hline 2002 & 55,6 & 23,1 & 76,9 & 44,4 & 68,6 & 32,1 & 67,9 & 31,4 \\
\hline 2003 & 56,9 & 21,4 & 78,6 & 43,1 & 66,4 & 31,2 & 68,8 & 33,6 \\
\hline 2004 & 55,7 & 19,2 & 80,8 & 44,3 & 67,7 & 32,4 & 67,6 & 32,3 \\
\hline 2005 & 58,0 & 22,6 & 77,4 & 42,0 & 68,0 & 34,0 & 66,0 & 32,0 \\
\hline 2006 & 57,9 & 27,8 & 72,2 & 42,1 & 72,2 & 33,2 & 66,8 & 27,8 \\
\hline 2007 & 65,6 & 28,8 & 71,2 & 34,4 & 69,4 & 31,2 & 68,8 & 30,6 \\
\hline 2008 & 64,6 & 28,6 & 71,4 & 35,4 & 64,7 & 27,4 & 72,6 & 35,4 \\
\hline 2009 & 66,6 & 29,8 & 70,2 & 33,4 & 65,2 & 32,6 & 67,4 & 34,8 \\
\hline 2010 & 66,7 & 28,6 & 71,4 & 33,3 & 66,4 & 31,8 & 68,2 & 33,7 \\
\hline$P$ & $0,000^{*}$ & $0,001^{*}$ & $0,001^{*}$ & $0,000^{*}$ & 0,449 & 0,186 & 0,185 & 0,437 \\
\hline
\end{tabular}

\begin{tabular}{|c|c|c|c|c|c|c|c|c|}
\hline \multirow[t]{3}{*}{ Věk } & \multicolumn{4}{|c|}{$6-10$ let } & \multicolumn{4}{|c|}{ 10-14 let } \\
\hline & \multicolumn{3}{|c|}{$\%$ prohlédnutých } & \multirow{2}{*}{$\begin{array}{c}\% \\
\text { neprohléd- } \\
\text { nutých }\end{array}$} & \multicolumn{3}{|c|}{$\%$ prohlédnutých } & \multirow{2}{*}{$\begin{array}{c}\% \\
\text { neprohléd- } \\
\text { nutých }\end{array}$} \\
\hline & alespoň 1x & $z$ toho $2 x$ & $\mathrm{z}$ toho $1 \mathrm{x}$ & & alespoň $1 x$ & $z$ toho $2 x$ & $\mathrm{z}$ toho $1 \mathrm{x}$ & \\
\hline 2001 & 82,6 & 48,4 & 51,6 & 17,4 & 82,8 & 62,4 & 37,6 & 17,2 \\
\hline 2002 & 84,2 & 46,2 & 53,8 & 15,8 & 87,4 & 58,8 & 41,2 & 12,6 \\
\hline 2003 & 79,4 & 46.0 & 54.0 & 20,6 & 86,2 & 61,2 & 38,8 & 13,8 \\
\hline 2004 & 87,7 & 51,3 & 48,7 & 12,3 & 84,6 & 56,4 & 43,6 & 15,4 \\
\hline 2005 & 79,5 & 50,8 & 49,2 & 20,5 & 83,4 & 60,8 & 39,2 & 16,6 \\
\hline 2006 & 87,6 & 55,5 & 44,5 & 12,4 & 91,5 & 74,2 & 25,8 & 8,5 \\
\hline 2007 & 78,6 & 49,8 & 50,2 & 21,4 & 87,8 & 68,4 & 31,6 & 12,2 \\
\hline 2008 & 86,9 & 58,5 & 41,5 & 13,1 & 90.0 & 72,5 & 27,5 & 10.0 \\
\hline 2009 & 83,9 & 57.0 & 43.0 & 16,1 & 85,9 & 69,4 & 30,6 & 14,1 \\
\hline 2010 & 85,2 & 58,8 & 41,2 & 14,8 & 88,7 & 71,1 & 28,9 & 11,3 \\
\hline$P$ & 0,558 & $0,001^{*}$ & $0,001^{*}$ & 0,558 & 0,125 & $0,012^{*}$ & $0,012^{*}$ & 0,393 \\
\hline
\end{tabular}

Regresní analýza - * signifikance trendu 
letech data vypovídají jen o větší polovině dětské populace, protože ostatní děti jsou pojištěnci jiných zdravotních pojištoven (tab. 1), dále jde o data o prohlídkách, které VZP stomatologickým zařízením jako prohlídky uhradila, a je nutné důvěřovat stomatologickým zařízením, že vykázané preventivní prohlídky skutečně provedla.

V předškolním věku absolvují v posledních letech zhruba dvě třetiny předškolních dětí preventivní prohlídku alespoň jedenkrát $\mathrm{v}$ roce a $\mathrm{z}$ nich menší třetina dvakrát v roce. U dětí školního věku je situa- ce příznivější, protože zhruba čtyři pětiny dětí jsou prohlédnuty alespoň jedenkrát v roce a z nich 30-40\% dvakrát ročně. Procento mladších předškolních dětí v posledních deseti letech signifikantně narůstalo, u ostatních věkových kategorií byl trend stabilní. Za příznivé lze pokládat to, že u mladších předškolních a u školních dětí signifikantně vzrưstal podíl dětí prohlédnutých dvakrát ročně.

Svou pozitivní roli zde pravděpodobně sehrálo zavedení Zubního průkazu dítěte Českou stomatologickou komorou v roce 2005 jako př́lohy Zdravotního

\begin{tabular}{|c|c|c|c|c|c|c|c|c|}
\hline \multirow[t]{2}{*}{ Věk } & \multicolumn{4}{|c|}{ 2-3 roky } & \multicolumn{4}{|c|}{$3-6$ let } \\
\hline & $\begin{array}{l}\% \text { prohléd- } \\
\text { nutých }\end{array}$ & $\begin{array}{c}\text { pouze } \\
\text { prohlídka }\end{array}$ & $\begin{array}{l}\text { prohlídka } \\
\text { + výplně }\end{array}$ & $\begin{array}{c}\text { prohlídka } \\
+ \text { extrakce }\end{array}$ & $\begin{array}{l}\text { \% prohléd- } \\
\text { nutých }\end{array}$ & $\begin{array}{l}\text { pouze } \\
\text { prohlídka }\end{array}$ & $\begin{array}{l}\text { prohlídka } \\
\text { + výplně }\end{array}$ & $\begin{array}{l}\text { prohlídka } \\
+ \text { extrakce }\end{array}$ \\
\hline 2001 & 49,1 & 44,2 & 44,5 & 11,3 & 67,4 & 38,4 & 56,8 & 4,8 \\
\hline 2002 & 55,6 & 42,6 & 43,8 & 13,6 & 68,6 & 36,3 & 57,3 & 6,4 \\
\hline 2003 & 56,9 & 46,4 & 48,4 & 5,2 & 66,4 & 31,2 & 60,7 & 8,1 \\
\hline 2004 & 55,7 & 46,7 & 47,3 & 6.0 & 67,7 & 39,5 & 56.0 & 4,5 \\
\hline 2005 & 58.0 & 44,9 & 49,3 & 5,8 & 68.0 & 40,8 & 52,6 & 6,6 \\
\hline 2006 & 57,9 & 47,4 & 48,1 & 4,5 & 72,2 & 38,3 & 52,1 & 9,6 \\
\hline 2007 & 65,6 & 45,8 & 46,2 & 8.0 & 69,4 & 41,2 & 53,6 & 5,2 \\
\hline 2008 & 64,6 & 48.0 & 43,4 & 8,6 & 64,7 & 42,1 & 47,5 & 10,4 \\
\hline 2009 & 66,6 & 49,3 & 44.0 & 6,7 & 65,2 & 43,1 & 48,2 & 8,7 \\
\hline 2010 & 66,7 & 48,9 & 44,8 & 6,3 & 66,4 & 46,8 & 45,2 & 8,0 \\
\hline$P$ & $0,000^{*}$ & $0,002^{*}$ & 0,55 & 0,185 & 0,451 & $0,007^{*}$ & $0,000^{*}$ & 0,099 \\
\hline
\end{tabular}

\begin{tabular}{|l|c|c|c|c|c|c|c|c|}
\hline Věk & \multicolumn{4}{|c|}{ 6-10 let } & \multicolumn{4}{c|}{ 10-14 let } \\
\hline & $\begin{array}{c}\text { \% prohléd- } \\
\text { nutých }\end{array}$ & $\begin{array}{c}\text { pouze } \\
\text { prohlídka }\end{array}$ & $\begin{array}{c}\text { prohlídka } \\
\text { + výplně }\end{array}$ & $\begin{array}{c}\text { prohlídka } \\
\text { + extrakce }\end{array}$ & $\begin{array}{c}\text { \% prohléd- } \\
\text { nutých }\end{array}$ & $\begin{array}{c}\text { pouze } \\
\text { prohlídka }\end{array}$ & $\begin{array}{c}\text { prohlídka } \\
\text { + výplně }\end{array}$ & $\begin{array}{c}\text { prohlídka } \\
\text { + extrakce }\end{array}$ \\
\hline 2001 & 49,1 & 44,2 & 44,5 & 11,3 & 82,8 & 83,5 & 6,8 & 9,7 \\
\hline 2002 & 55,6 & 42,6 & 43,8 & 13,6 & 87,4 & 89,4 & 9,4 & 1,2 \\
\hline 2003 & 56,9 & 46,4 & 48,4 & 5,2 & 86,2 & 88,8 & 5,4 & 5,8 \\
\hline 2004 & 55,7 & 46,7 & 47,3 & 6.0 & 84,6 & 86,7 & 12,5 & 0,8 \\
\hline 2005 & 58.0 & 44,9 & 49,3 & 5,8 & 83,4 & 84,7 & 13,5 & 1,8 \\
\hline 2006 & 57,9 & 47,4 & 48,1 & 4,5 & 91,5 & 82,5 & 16,1 & 1,4 \\
\hline 2007 & 65,6 & 45,8 & 46,2 & 8.0 & 87,8 & 86,5 & 10,8 & 2,7 \\
\hline 2008 & 64,6 & 48,0 & 43,4 & 8,6 & 90.0 & 89,4 & 9,2 & 1,4 \\
\hline 2009 & 66,6 & 49,3 & 44.0 & 6,7 & 85,9 & 83,8 & 12,4 & 3,8 \\
\hline 2010 & 66,7 & 48,9 & 44,8 & 4,8 & 88,7 & 88,7 & 7,6 & 3,7 \\
\hline P & $\mathbf{0 , 0 0 0 *}$ & $\mathbf{0 , 0 0 2 *}$ & 0,55 & 0,185 & 0,125 & 0,881 & 0,491 & 0,321 \\
\hline
\end{tabular}

Regresní analýza - *signifikance trendu 
a očkovacího průkazu dítěte a mladistvého. Ten je připomínkou poskytovatelům primární pediatrické péče i rodičům $k$ včasné registraci dítěte ve stomatologickém zařízení a zahájení pravidelných preventivních stomatologických prohlídek. Ve stejném roce byl v Brazílii implementován preventivní program Zdravá rodina, jehož součástí byla informační kampaň o očkování a zavedení očkovacích průkazů pro děti. Po dvou letech pilotní studie byl zaznamenán nárůst počtu dětí registrovaných do zubní péče ve zdravotních centrech pro rodiny s dětmi [15].

Nepříznivým zjištěním je, že třetina předškolních dětí a pětina školních dětí neabsolvuje každoročně preventivní stomatologickou prohlídku. $\mathrm{Z}$ toho je patrný deficit odpovědnosti části rodičũ za péči o chrup jejich dětí.

Jak nedávno prokázali Ivančaková a kol. [9], meziroční př́růstek kazu se významně zvyšuje ve věku kolem 3-4 let. Plyne $z$ toho, že by co nejvíce starších předškolních dětí mělo absolvovat preventivní prohlídku dvakrát ročně, aby se co nejvíce vznikajících kazivých lézí diagnostikovalo a ošetřilo $v$ počátečním stadiu. $\mathrm{V}$ tomto věku jsou však jen dvě třetiny dětí prohlédnuty alespoň jedenkrát ročně $a z$ nich jen třetina dvakrát ročně.

Ve školním věku je četnost prohlídek ve srovnání s předškolním věkem vyšší, přesto však $10-15 \%$ dětí není každoročně vyšetřeno.

Při porovnání ukazatelů prohlídek v jednotlivých krajích v roce 2010 lze zaznamenat určité rozdíly, které se však neuplatňují ve všech sledovaných věkových kategoriích předškolních a školních dětí. Hlavní město Praha se od ostatních regionů neliší tak výrazně, jako je vidět v sestavách dat o meziregionálních četnostech úrovně prohlídek např. v Austrálii [8], ve Velké Británii [7] nebo v Brazílii [3] mezi velkoměsty a venkovskými regiony.

Data o preventivních prohlídkách u českých dětí lze obtížně srovnávat s dětmi z jiných zemí, protože v zahraničí se tyto údaje obvykle získávají formou dotazníků, a mohou tak být zatíženy neodhadnutelnými nepřesnostmi. Naše situace, byt ne př́liš příznivá, se však zásadně neliší od jiných zemí, když např̀. nedávná studie provedená v Belgii ukázala, že $62 \%$ tříletých dětí ještě neabsolvovalo preventivní stomatologickou prohlídku a $\mathrm{v}$ pěti letech to byla ješsě pětina dětí [11].

Nízká četnost prohlídek u dětí z nižších sociálních vrstev populace se $\mathrm{v}$ zahraniční literatuře přičítá nižší dostupnosti stomatologické péče, bud' kvưli nižší denzitě stomatologických zařízení nebo ceně prohlídek a ošetření, diverzifikaci populace ve vzdělanostních a ekonomických ukazatelích nebo lokalitě bydliště.
Různá hustota sítě stomatologických zařízení v jednotlivých regionech ČR na četnosti prohlídek u dětí zřejmě roli nehraje, protože počty předškolních a školních dětí, které jsou alespoň jedenkrát za rok vyšetřeny s ukazatelem hustoty (počet obyvatel, resp. dětí na jednoho zubního lékaře) spolu nekorelují $(\mathrm{p}=0,817)[5,17]$ a úhrada prohlídek se rodinných rozpočtů netýká.

V dosud nepublikovaném dotazníkovém šetření [Černý a spol. 2012] uváděli rodiče s nižším vzděláním a žijící v menších sídlech významně nižší četnost a nižší pravidelnost prohlídek u předškolních a školních dětí než rodiče $s$ vyšším vzděláním žijící ve větších sídlech.

Nízká četnost a nepravidelnost preventivních prohlídek zejména u předškolních dětí je slabou stránkou všech systémů stomatologické péče, kde o ní rozhodují rodiče. Hledají a prověřují se možnosti (připomínky, upozornění rodičũ ze strany poskytovatelů stomatologické péče), které by mohly četnost stomatologických prohlídek zvýšit. Účinnost těchto připomínek nedávno prokázala studie v USA, kdy jednorázová připomínka rodičưm formou telefonického hovoru zvýšila četnost prohlídek u dětí o 8,2 \% a zaslání SMS zprávy o 17,7 procent [13] .

Je známo, že i v systémech stomatologické péče, ve kterých jsou děti zvány na preventivní prohlídky, část rodičů tyto výzvy nerespektuje nebo $\mathrm{v}$ pravidelnosti prohlídek selhává. Ve studii provedené v Norsku nerespektovalo takovouto výzvu v průběhu dvou let $15 \%$ rodičũ alespoň jedenkrát a $5 \%$ nereagovalo vůbec. Při prohlídkách, které se nakonec uskutečnily, se zjistilo, že děti s nepravidelnou docházkou k prohlídkám měly signifikantně vyšší kazivost a vyšší počet nových kazů ve srovnání s dětmi, které docházely na preventivní prohlídky pravidelně [18] . $\mathrm{V}$ podobné studii provedené ve Velké Británii nereagovalo na písemnou výzvu k preventivní prohlídce až $25 \%$ rodičũu [14].

Jiným nástrojem, uplatňovaným ve Velké Británii, je skupinový screening ve školních zařízeních s následným upozorněním rodičů o potřebě stomatologické péče. Účinnost tohoto opatření je však závislá na socioekonomickém postavení rodin, protože rodiče $z$ vyšší sociální vrstvy reagovali na upozornění potřeby péče signifikantně častěji než rodiče z nižších vrstev [12].

Při kalkulaci četnosti stomatologických prohlídek $z$ datových souborů zdravotní pojištovny nelze zjistit důvod návštěvy dítěte ve stomatologickém zařízení. Vycházeli jsme $z$ této úvahy:

Pokud byla u daného dítěte $v$ jednom dni pojištovně vykázána pouze preventivní prohlídka, zjistil se př̀ ní bud' intaktní, nebo sanovaný chrup, nebo 
potřeba ošetření odložitelná na objednací termín další návštěvy. Důvodem návštěvy byl pravděpodobně zájem rodičũ o preventivní prohlídku u jejich dítěte. Pokud bylo společně s prohlídkou vykazováno i nějaké konzervační ošetření nebo extrakce zubu, byl důvodem návštěvy spíš zájem rodičů o vyřešení nastalého problému se zuby jejich dětí než preventivní prohlídka.

U zhruba 45 \% předškolních a mladších školních dětí bylo spolu s preventivní prohlídkou vykázáno ošetření výplní (výplněmi) a u 6-8 \% dětí extrakce zubu. Extrakce zubu u dětí předškolního věku (2-3leté a 3-Gleté) mohly mít stěží jiný důvod než komplikace pokročilého kazu.

Potřeba urgentní péče v průběhu prohlídek byla nepochybně nižší a řada konzervačních nebo extrakčních výkonư mohla být provedena díky momentálním časovým možnostem stomatologického pracoviště. V posledním celostátním průzkumu stavu chrupu a ošetření v roce 2006 v ČR byla akutní potřeba extrakce v okamžiku prohlídky zaznamenána jen u 0,1\% pětiletých a u 0,06\% 12letých dětí [2].

Přestože se stav chrupu a potřeby ošetření ve sledovaných ukazatelích v naší dětské populaci zlepšují $[1,10]$, ukazatele preventivních prohlídek a trend jejich vývoje v posledních letech ukazuje slabiny současného systému dětské stomatologické péče, který nemá účinné nástroje na zvýšení dostupnosti preventivních prohlídek u předškolních a školních dětí.

\section{ZÁVĔR}

Preventivní stomatologické prohlídky absolvují zhruba dvě třetiny předškolních a čtyři pětiny školních dětí alespoň jedenkrát v roce. $Z$ nich jedna třetina předškolních a více než dvě třetiny školních dětí jsou prohlédnuty dvakrát v roce. Zdravotní výchova populace $v$ individuálním i komunitním měřítku by měla zvýšit dưraz na plošné zařazení dětí do stomatologické péče a na pravidelné prohlídky chrupu.

\section{LITERATURA}

1. Balkova, S., Lencova, E., Broukal, Z.: Trends in oral health of children and adolescents in the Czech Republic 1994-2006. 13 $3^{\text {th }}$ Annual Congress EADPH, 2008, Heidelberg, Programme and Abstracxts Book, Abstr. No. 4039.

2. Bourgeois, D. M., Llodra, J. C., Nordblad, A., Pitts, N. B.: Report of the EGOHID I Project. Selecting a coherent set of indicators for monitoring and evaluating oral health in Europe: criteria, methods and results from the EGOHID I project. Community Dent. Health, roč. 25, 2008, č.1, s. 4-10.

3. Cunha, R. F., Zaze, A. C., Vieira, A. E., Melhado, F. L., Sundefeld, M. L.: Longitudinal behavioral analysis during dental care of children aged 0 to 3 years. Braz. Oral Res., roč. 23, 2009, č. 3, s. 302-306.
4. Čsú 2010 - Demografická data. http://www.czso.cz/csu/redakce.nsf/i/obyvatelstvo_lide

5. ČSK Ročenka 2010. http://www.dent.cz/detail-text.php?id_ strana=3\&id text $=48$

6. ČSK 2011 - Seznam stomatologických výkonů. http://domino. dent.cz/csk/sml_zp.nsf/Vykony?OpenView

7. Eckersley, A. J., Blinkhorn, F. A.: Dental attendance and dental health behaviour in children from deprived and non-deprived areas of Salford, north-west England. Int. J. Paediatr. Dent., roč. 11, 2001, č. 2, s. 103-109.

8. Ellershaw, A. C., Spencer, A. J.: Dental attendance patterns and oral health status. Australian Institute of Health and Welfare Canberra, 2011, ISBN 978-1-74249-132-5, http://www.arcpoh.adelaide.edu.au/publications/report/statistics/pdf_11/DSR\%2057

9. Ivančaková, R., Broukal, Z., Oganessian, E., Lenčová, E.: Prospektivní třiletá studie prírůstku zubního kazu u starších předškolních dětí. Čes. Stomat., roč. 112, 2012, č. 5, s. 118-127.

10. Lencova, E., Pikhart, H., Broukal, Z.: Early childhood caries trends and surveillance shortcomings in the Czech Republic. BMC Public Health, 2012, 12:547 doi:10.1186/1471-2458-12-547.

11. Leroy, R., Bogaerts, K., Hoppenbrouwers, K., Martens, L. C., Declerck, D.: Dental attendance in preschool children a prospective study. Int. J. Paediatr. Dent., 2012 Feb 22. doi: 10.1111/j.1365-263X.2012.01227.x.

12. Milsom, K. M., Threlfall, A. G., Blinkhorn, A. S., KearneyMitchell, P. I., Buchanan, K. M., Tickle, M.: The effectiveness of school dental screening: dental attendance and treatment of those screened positive. Brit. Dent. J., roč. 200, 2006, č. 12, s. 687-690.

13. Nelson, T. M., Berg, J. H., Bell, J. F., Leggott, P. J., Seminario, A. L.: Assessing the effectiveness of text messages as appointment reminders in a pediatric dental setting. J. Am. Dent. Assoc., roč. 142, 2011, č. 4, s. 397-405.

14. Reekie, D., Devlin, H., Worthington, H.: The prevention of failed appointments in general dental practice. Brit. Dent. J., roč. 182, 1997, č. 4, s. 139-143.

15. Stocco, G., Baldani, M. H.: The control of babies' dental visits through the vaccines card: evaluating a pilot program developed at the Family Health Strategy at Ponta Grossa (PR, Brazil). Cien. Saude Colet., roč. 16, 2011, č. 4, s. 2311-2321.

16. Vyhláška MZ ČR o stanovení obsahu a časového rozmezí preventivních prohlídek. Sbírka zákonů 2010, částka 3, s. 6-10.

17. VZP Výroční zprávy 2001-2010. http://www.vzp.cz/o-nas/dokumenty/vyrocni-zpravy

18. Wang, N.J., Aspelund, G.Ø.: Children who break dental appointments. Eur. Arch. Paediatr. Dent., roč. 10, 2009, č. 1, s. 11-14.

19. Zákon. č. 48/1997 Sb. o veřejném zdravotním pojištění a o změně a dopInění některých souvisejících zákonů. Sbírka zákonů ČR 1997, částka 16, s. 1185-1264.

Studie byla podpořena projektem PRVOUK reg. č. P 28/LF1/6.

Prof. MUDr. Zdeněk Broukal, CSc. Ústav klinické a experimentální stomatologie

1. LF UK a VFN

Karlovo nám. 32

12111 Praha 2

e-mail: broukal@vus.cz 